Article

\title{
Tourism and Taxonomy: Marianne Moore and Natasha Trethewey in Jefferson's Virginia
}

\author{
Linda Kinnahan \\ Professor of English, Duquesne University, Pittsburgh, PA 15282, USA; kinnahan@duq.edu \\ Received: 4 September 2019; Accepted: 12 November 2019; Published: 24 November 2019
}

\begin{abstract}
In the poetry of modernist Marianne Moore and contemporary American poet Natasha Trethewey, we find tours of historic places that are associated with the country's founding history. How does the activity of the tour contemplate the ways in which historical knowledge takes shape and around what priorities and ideals? Exploring this question, these poems stage touristic encounters that serve not only to document the places visited but to question the frames by which a site is "seen" in relation to-often in support of-selected versions of American history. The impact of systems of classification and categorization that are common to the development of taxonomic thought, embraced by Thomas Jefferson and other early Americans, comes under inspection in these touristic poems.
\end{abstract}

Keywords: race; tourism; taxonomy; poetics; Marianne Moore; Natasha Trethewey; Thomas Jefferson

"Observe the terse Virginian", Marianne Moore instructs in "Virginia Britannia", calling our attention to historical and natural details while leading her reader on a poetic tour of the colonial sites of Jamestown and Williamsburg, taking us past the "church-floor brick/and Sir George Yeardley's/coffin-tacks and tomb" below the "church tower" marking America's first settlement (Moore 1936, pp. 3, 5). ${ }^{1}$ Moore wrote the poem after visiting the restorations of these early colonial places in 1935. Some eighty years later, Natasha Trethewey flings open the doors to Monticello, the home of Thomas Jefferson, drawing our attention in her tour to the "portrait of Jefferson" hanging in the entrance hall and observing the play of light and dark across his face (Trethewey 2012, p. 68). Observe, suggest both poets, but then question how you are observing in these tours of places rich with history and evocations of America's nation building. How does the activity of the tour contemplate the ways in which historical knowledge takes shape and around what priorities and ideals? Exploring this question, these poems stage touristic encounters that serve not only to document the places visited, but also to question the frames by which a site is "seen" in relation to-often in support of-selected versions of American history.

These frames, for both Moore and Trethewey, reveal the power of the Enlightenment development of taxonomy, with its classifications and catalogues, to shape the presentation of place in line with particular versions of American history. This essay will consider each poet's exploration of the tourist site as a way of contemplating American history. Significantly, both of the poets explore how prevailing historical narratives shape touristic sites around ideas of nation, national identity, and place; moreover, such historical narratives are subject to interrogation and change. Moore's visit to Virginia and Trethewey's visit to Monticello occur, respectively, at important moments of physical and narrative renovation in places that are associated with America's founding. When Moore visited Virginia in the 1930s, architectural and structural renovations taking place in Williamsburg aimed to enhance tourism's role in educating an American public through celebrating American principles; at the same

1 This essay references the presentation of "Virginia Britannia" appearing in Moore's 1936 Pangolin and Other Verse. All page numbers for this poem reference Moore's volume, which has been reprinted in facsimile form in White (2008). 
time, Williamsburg's presentation of America's past elided difficult questions regarding that history, particularly in relation to structures of inequality. For Trethewey, visiting the home of Thomas Jefferson in the twenty-first century, the aftermath of DNA tests establishing genetic links between Jefferson and African American descendants of his slave Sally Hemings compels Monticello's efforts to re-develop the touristic experience to more fully admit this erased history; however, old habits of thinking regarding racial identity linger.

Moore and Trethewey stage touristic encounters that serve not only to document the places visited, but to question the frames by which a site is seen in relation to-and often in support of-selected versions of American history. For both poets, the touristic experience reveals a history of racial contradictions, motivating poems attentive to the relationship of taxonomy with racial bias. Indeed, the impact of systems of classification and categorization common to the development of taxonomic thought, as embraced by early American Enlightenment thinkers, comes under inspection in these touristic poems. The taxonomies shown to be structuring the tourist site and experience reveal how classifications of race have always been central to the histories of America told (and concealed) through places central to those histories.

To think about taxonomy as a way in which the Enlightenment attempted to order and understand the natural and social worlds recalls the American figure most responsible for bringing such practices into this country, Thomas Jefferson. Touring Jefferson's home in the twenty-first century, Tretheway's poem "Enlightenment" explores the persistence of taxonomies of race that he endorsed, as the poem inter-splices her contemporary biracial experience in private, familial, and public contexts. Trethewey quite directly interrogates Thomas Jefferson's taxonomies of race within broader systems of racial identification in the early Americas. This poem, part of her 2012 volume Thrall, joins a collection of poems explicitly foregrounding natural history's logic of taxonomies as a way of organizing race in the "new world", most systematically explored in the sequence "Taxonomies".

While "Taxonomies" focuses upon the Spanish conquest of the Americas, Thrall links the past and present of the United States to the racial classifications emerging from the larger European colonial project and the concurrent slave trade. Moore's "Virginia Britannia", the first of four poems in the sequence "Old Dominion" and published in The Pangolin and Other Verse (1936), considers this founding colony in relation to the paradox of the American experiment, the justification of racial hierarchies, and oppressions as part of a Manifest Destiny of nation building. For both Moore and Trethewey, Jefferson represents an American contraction, haunting both poems in the "shadows" (in Moore's allusion to him) cast by the racial contexts of the country's founding that retain force in contemporary culture. For Trethewey, the colonial history of the Americas informing Jefferson's thinking indicates the "dark subtext" of American history, the racial cartography shaping sites, and narratives of the country's founding (Trethewey 2012, p. 68). Subsequently, the tour becomes an important act in discerning this cartography; indeed, the poet as tourist encounters place as a taxonomy to be explored, historicized, and made strange.

\section{Early Moore and Taxonomy as Documentary Tourism}

Not unlike other modernists, tourism becomes a subject of choice for Moore early on, writing poems in the 1910s and 1920s that respond to places she visits and recording these visits in extensive, precise details based on keen observation, but also freely drawing from multiple, myriad sources. Moore's travel notebooks, which she kept religiously, record many of the observations and details that find their way into poems. ${ }^{2}$ Engaging what might be called a technique of "documentary tourism", her poem "An Octopus", like other long (and some short) poems in her 1924 volume Observations, displays characteristics of her experimental verse: the poem engages an obsessive cataloguing of

2 See the Marianne Moore Digital Archive for information about Moore's notebooks and annotated editions published on line and forthcoming. http://moorearchive.org/. 
precise detail drawn from nature, history, science, art, and all manner of extra-poetic sources; includes a formal reliance upon other documents, such as the insertion of full and partial quotations within poems; and, provides extensive, but incomplete, notes that end this first book. These often copious "Notes" inconsistently and incompletely cite sources referenced and/or quoted in the poems, contributing to while also complicating a poetic form of documentary tourism. The documentary function of notes, gesturing toward a record of sources however incomplete, joins with other documentary practices that include her use of documents (including documents of tourism), the accumulation of evidentiary detail, and a reliance upon empirical means in proffering a density of fact and observation.

This stress on documentary practice distinguishes Moore's touristic poems from those of fellow modernists for whom the figure of the modern tourist and the advent of mass tourism accompanied a critique of the new century's shallowness. Most strikingly, her fellow poet Ezra Pound disdained a bourgeois sensibility that he saw permeating modern tourism, and he used the tourist as a foil to advancing a new poetics, an avant-garde corrective for a deficient national culture. While both Moore and Pound shared a "preoccupation with nation-building narratives", Moore regards the touristic moment as an opportunity to investigate those narratives, while Pound's poetry suggests that they reveal the populace's shallow sense of national character or tradition (Green 2017, p. 428).

Pound's tourist offers a useful contrast to Moore's sense of the tour as a skeptical engagement with history. In poems, Moore would likely have read while formulating her own first efforts to write as a modern poet, Pound skewers a middle-brow superficiality among tourists he perceives as bereft of history. The first issue of Poetry (October 1912) includes Pound's foray with an American audience in proclaiming an avant-garde poetics. His assertion of avant-gardism explicitly takes aim at the "mass of dolts" and the "frolicking tourists" in two poems relating touristic activities-visiting a museum and viewing an ancient tomb. "To Whistler, American", a poem responding to the Whistler exhibit at the Tate, and "Middle-Aged: A Study of Emotion", set among the pyramids, both regale unrefined visitors. The popular masses clustering at sites of cultural significance promote Pound's sense of urgency in calling for the emergence of a superior and oppositional "us", an avant-garde of innovation and poetic vision. This is an old story in modernist avant-garde formations- the artist versus the middlebrow masses-but Pound's particular language about tourism and the oppositional poses that he adopts as speaker warrant attention and throw into relief the different tack taken by Moore in regard to the tourist and the tour.

In "To Whistler, American", the painter enables the oppositional "us" of the poem and the battle to be in front (avant-garde) of "our America" through "our art" and its newness. Addressing Whistler, the poem acclaims Whistler's example for "us":

You, our first great...

... for us, I mean.

Who bear the brunt of our America

And try to wrench her impulse into art.

You were not always sure, not always set...

Had not one style from birth, but tried and pried

And tampered with the media. (Pound 1912b, p. 7)

The poet's visit to the museum stakes a claim to a masculine lineage of artists, encouraging leadership through factional battle or struggle that distinguishes the "avant" from the "dolts":

You and Abe Lincoln from that mass of dolts

Show us there's chance at least of winning through. (Pound 1912b, p. 7)

The artist, then, is not the run-of-the-mill tourist, but it is capable of enabling new forms of culture through connecting aesthetically and historically with the museum or other touristic site. In contrast, the "mass of dolts" from which he separates himself in the museum inhabits the second poem "Middle-Aged". Their careless encounters with the great pyramids and buried kings are 
figured in images of "Tourists frolicking" among the ancient sites, snapping photographs with newly portable cameras. This technology of representation links to their own modern state of transitory, inconsequential engagement with history, and art. They

Try photographs, wolf down their ale and cakes

And start to inspect some further pyramids...

Their transitory step and merriment. .. (Pound 1912a, p. 8)

Pound's antipathy toward the masses infamously led him two years later to assert that the "'man in the street' cannot be expected" to grasp authentic art (in this case, Wyndham's Lewis' "Timon", his Cubo-Futurist illustrations of Shakespeare's Timon of Athens): "Damn the man in the street, once and for all, damn the man in the street who is only in the street because he hasn't intelligence enough to be let in to anywhere else" (Pound 1914, p. 233). Pound's disdain echoes in his presentation of the common tourist who enters the museum unaware, trampling over the tombs—and all of history-with "transitory step and merriment" (Pound 1912a, p. 8).

Marianne Moore is not persuaded to join Pound's avant-garde campaign against the "man of the street". Indeed, Moore's poems of the teens and twenties comment repeatedly on this kind of disdain, linking it to material forms of power dramatically expressed in her 1924 long poem "Marriage", which evokes litanies of history and empirical evidence to observe how "experience attests/that men have power/and sometimes one is made to feel $\mathrm{it}^{\prime \prime} .{ }^{3}$ In many poems, authority and power are shown to be human constructions and systems that too effectively naturalize meaning, concealing their social bias in promoting a natural truth. Early poems perceive that the organization of knowledge, such as constructed taxonomies and classification systems, is never a neutral act. "A Fool, A Foul Thing, a Distressful Lunatic", a poem ostensibly about derided birds, questions how the western preference for classification and cataloguing enables a system that privileges certain versions of knowledge while claiming objectivity. The poem recalls types of birds and their humanly-associated qualities, relating, for example, that the "gander" is "Mocked, and ignorantly designated yet/To play the fool" (Moore 2016, p.12). Similarly, Egyptian vultures are deemed "foul", and the loon is "foremost in the madman's alphabet". Moore expresses skepticism over assuming each bird's nature as such, instead asking whether it is not a "folly's catalogue" that "styled" these creatures so, stressing that the cultural structures organizing knowledge are themselves suspect in assessing nature (Moore 2016, p. 12, emphasis added). Intriguingly, this skepticism regarding the catalogue as a structure of knowledge reoccurs in poems that at the same time deeply invest in cataloguing as a method of procedure or a formal poetics for her information-laden poems. The catalogue, as a system of classification, becomes both an architectural feature of Moore's poems and subject to critique for naturalizing definitions and sites of power.

This dual practice of deploying classification and a suspicion of it informs the documentary tourism of "An Octopus", written in 1924 following a trip to Washington state with her mother and her brother Warner. "An Octopus" relates what she sees in their excursions to Mount Rainier National Park where the trio stayed for two days amidst dazzling views of the mountain and alpine meadows, and Moore hiked with her brother in the ice caves (Leavell 2016, p. 200). "An Octopus" presents the glacier as itself a documentary force of "accuracy" and "fact", adopting language that is within the next decade will become synonymous with the new term "documentary": "Relentless accuracy is the nature of this octopus/with its capacity for fact" (Moore 2016, p. 91). Constructed as a catalogue of documents, the poem insistently gathers myriad references and quotes (both exact and off-quotes) from a mixed range of texts. Among the quoted sources in the poem, which include such high-culture luminaries as Newman, Trollope, and Ruskin, Moore draws upon among popular visual media, like the Illustrated London News and the London Graphic; however, her most insistently inserted sources are from tourist

3 Observations, 80. All quotes from this volume will reference the 2016 edition edited by Linda Leavell. Observations was originally published in 1924 by Dial press, with a second (and slightly revised) edition in 1925. 
brochures, pamphlets, and books, including W.D. Wilcox's The Rockies in Canada, Clifton Johnson's What to See in America, and what Moore's notes tells us are copious, but uncited uses of "government pamphlets on our national parks" for "descriptions of scenery and of animals" (Moore 2016, p. 109). Johnson's travel guide describes in great detail the natural abundance and visual grandeur of Mt. Rainier, providing the metaphor of the octopus that Moore adopts: "From the snow-covered summit twenty-eight rivers of ice pour slowly down the gashed slopes, reaching into the rich gardens of wild flowers and splendid ever-green forests like the tentacles of a huge octopus" (Johnson 1922, p. 534).

Especially through this intertextuality, the poem installs the tourist in the poem as witness and documentarian, but also as the instrument through whom the apparatus of tourism and tourist guidebooks is filtered. The tourist, the tourism materials, and the poem's overwhelming "capacity for fact" evolve a documentary approach that is characterized by what the poem calls a "relentless accuracy", recalling the cropped, highly focused precision of contemporaneous photographers, like Paul Strand or Ralph Steiner, at the forefront of documentary photography. Note the cropped, up-close focus and precision of detail in the following set of lines:

Larkspur, blue pincushions, blue peas, and lupin;

white flowers with white, and red with red;

the blue ones "growing close together

so that patches of them look like blue water in the distance";

this arrangement of colors

as in Persian designs of hard stones with enamel,

forms a pleasing equation-

a diamond outside and inside, a white dot;

on the outside, a ruby, inside, a red dot;

black spots balanced with black

in the woodlands where fires have run over the ground-

separated by aspens, cat's paws, and woolly sunflowers,

fireweed, asters, and Goliath thistles

"flowering at all altitudes as multiplicitous as barley",

like pink sapphires in the pavement of the glistening plateau.

Inimical to "bristling, puny, swearing men

equipped with saws and axes",

this treacherous glass mountain

admires gentians, ladyslippers, harebells, mountain dryads,

and "Calypso, the goat flower-

that greenish orchid fond of snow" - (Moore 2016, p. 89)

Moore's emphasis on this specifically American natural place informs how she formulates the touristic moment. Pound's mockery of the tourist is a broader critique of the thinness of modern culture, and particularly of the lack of substance (for him) of American culture. His portrayals of the middle-brow American tourist show their encounters with the grandness of ancient history as a kind of entertainment or spectacle (being cheaply reproduced through the modern technology of the photograph), emphatically transpiring on non-American ground. In part, this depiction plays into the image of the American and America as culture-less in comparison with Europe and more ancient sites of western culture, an image long plaguing the newer country's sense of identity (as we will see in later discussions of Thomas Jefferson). Moore's poems suggest a different relationship between the tourist, place, and history that are activated by the tourist-poet's engagement in deep empirical observations of both natural and human activity in American places. We see this empirical approach in the precision used to describe Mt. Rainier, rendering a panoply of close-up details that becomes disorienting and suggests a kind of witness enacted through making the American place strange or defamiliarized in the act of witnessing. 
The advent of mass tourism, as critiqued by Pound, suggests for Moore a democratization of national identity and an access to the past that nonetheless must be skeptically and responsibly inspected by the touristic citizen. Encouraging a (profitable) relationship between touristic places and a sense of American identity was a central motivation in the expanding tourist industry, which between 1880 and 1940 spurred a "national tourism" that "emerged as a form of geographical consumption that centered on the sights and scenes of the American nation" (Shaffer 2001, p. 3). Responding to a national market and being enabled by "methods of mass production and mass distribution ... [and] an expanding middle class with time and money to spend on leisure", tourism was "integrally connected to the emergence of the United States as a corporate, urban-industrial nation-state", and "actively promoted" as "a ritual of American citizenship. Commercial clubs, railroad corporations, the National Park Service, good-roads advocates, guidebook publishers, and a wide array of tourist advocates and enthusiasts defined the tourist experience in national terms" (Shaffer 2001, p. 4). For Moore, such experiences held the potential to enable American citizenry, but demanded a particularly informed skepticism toward inherited narratives.

An embrace of American places, alongside a questioning of idealistic histories, marks Moore's poetic encounter with Mt. Rainier, as "An Octopus" heralds the rich beauty of the American landscape, echoing tourist pamphlets and guidebooks of the time that "created and marketed tourist landscapes as quintessentially American places" (Shaffer 2001, p. 4). The poem describes the mountain's fir trees, for example, as the "austere specimens of our American royal families" (Moore 2016, p. 85). Tourist guides from this period aimed to "teach [ ... ] tourists what to see and how to see" American places, thus creating "an idealized American history and tradition across the American landscape", as Marguerite Shaffer argues (Shaffer 2001, p. 4). At the same time, Moore's "An Octopus" explicitly decries the human activity threatening this monumental natural environment. The environmental awareness suffusing the poem channels into momentary critiques of the economic forces compelling tourism, as in the inclusion of loggers chopping up the complex natural habitat the poem has assiduously documented. In the long quoted passage above, the activities of men interrupt the cascading catalogue of natural details. Although much of nature is preserved- "glacial ledges" remain "where climbers have not gone or have gone timidly" - the intrusion of men and financial profit threatens the glacier, although its might remains

Inimical to "bristling, puny, swearing men Equipped with saws and axes" (Moore 2016, p. 89)

Conjoining the "climbers" and the loggers, these lines gesture toward the financial project of tourism and its potential to harm the environment.

Interestingly, Moore's eco-critical gloss echoes a tension between idealized representations of place and critical concern with the environment that appears in tourist literature at this time; indeed, her reference to the loggers directly connects the poem to environmental commentary that surfaces in tourism guides. Placed within quotation marks in the poem (although inaccurately quoted), "bristling, puny, swearing men" first appear in Clifton Johnson's What to See in America, cited in Moore's notes as her source, although his comments are directed more broadly at the modernizing logging industry invading Washington state's forests: "Steam has made of logging in its forests a business which devastates them with incredible speed and system", and tracts cut through the forest resemble "the trail of a cyclone" (Johnson 1922, p. 537). Linking the forests' old growth to American identity, Johnson attributes to the natural landscape an essential national quality and criticizes environmental abuse as damaging American character: "Many of them [trees] have been growing since the time when Columbus found this continent of ours-and they are doomed to be destroyed by puny bustling swearing men with saws and axes" (Johnson 1922, p. 537, emphasis added). Johnson's tour guide provides a detailed and rather lengthy report on the destructive process of logging. Moore's poem, through its documentary strategies and detailed classifications, suggests how the natural environment is narrated for ideological purposes (such as supporting American exceptionalism through reverence for its natural 
bounty and space), while alternative narratives (especially commercial ones, like logging) conjure a more complex notion of "history" and "nature" and "nation".

\section{Taxonomy, American History, and Tourism}

The contradictions surfacing in tourism literature at the time that Moore wrote "An Octopus", between an idealized land and an environmentally compromised American landscape, compel an awareness that the profit-driven tourist industry itself was or would have an environmental impact. In this poem, the documentary habits of observation, cataloguing, and collecting compel the tourist's understanding of her encounter with nature as an encounter with socio-historical and economic constructions. A decade later, in "Virginia Britannia", the empirical documentary tools of catalogue and classification echo and question the taxomomic approach of natural history as a way of organizing knowledge regarding the world. Suggesting a generational link with Moore across some six or more decades, Natasha Trethewey's Thrall confronts the continuing social force of taxomomic thinking and practice on racial understanding in America.

In 1935-1936, Moore wrote a four-poem sequence, "Old Dominion", employing a strictly disciplined syllabic verse to consider both the natural world and the sociohistorical dimensions of the state of Virginia, following a visit Moore took with her mother and brother (stationed in Norfolk) that included tours of Jamestown and Williamsburg. ${ }^{4}$ The first poem, "Virginia Britannia", conducts a "tour" of these early sites of American history and references the city of Charlottesville, although it is not clear whether she visited there or depended for her brief reference upon her reading through the "prides of Virginia, as found on my bookshelf" during her stay in Virginia in late summer, $1935 .{ }^{5}$ She visited Williamsburg initially in 1927, but upon her 1935 visit the National Park Service was restoring the town and its historical buildings and grounds (along with Jamestown), attracting tourists who were eager to see this founding American site. ${ }^{6}$ The surge in American tourism, especially after the war, promoted particular ways of viewing historical sites that the reconstruction of Williamsburg enacted. The popular travel guides, See America First, for example, had since the teens encouraged travelers to understand a "particular narrative of history":

... the act of marking these historic sites and literary shrines went beyond the desire to bolster the existence of an American tradition. The guides did not simply celebrate a generic ideal of history, they defined a very particular narrative of American history by deliberately selecting and presenting certain historical facts. In mapping and deciphering the landmarks of history, the series chronicled the process by which the boundaries of the nation were formed. The guides described the march of history as a series of conquests [Spanish, French, English] ... Finally, the Americans, united in their quest for freedom and democracy, broke the bonds of empire and expanded across the continent, conquering the Indians and forging a free and democratic nation. Through this narrative the guides presented the stages of American development, inventing an American tradition that reinforced the Progressive era's

4 The sequence is first published in The Pangolin and Other Verse, 1936. All page references are to this volume, which is included in facsimile form in (White 2008).

5 Moore (1997, p. 350). In this letter, Moore is writing to Hildegarde Watson, August 8, 1935, during her stay in Portsmouth, Virginia that summer. She and her mother returned to Virginia the following summer.

6 Green (2017, p. 433). Usefully claiming that Moore's visits to reconstructed Williamsburg and Jamestown "prompted Moore to think about a national narrative as a special kind of construction," Green reads the poem as sympathetic to a romantic "cavalier myth" of "southern historiography" that sees a necessity for slavery "to secure the independence of the cavalier planter, and eventually, that of the nation" (p. 439). See also Miller (1995), on race and Moore; Westover (2004), on Moore's (1967) treatment of American settlement history (Westover treats Moore's final version of the poem as it appears in 1967 in The Complete Poems, while this essay considers its first presentation in 1936). See Stubbs 2016. Stubbs discusses ideas of nationality in this "Virginia Britannia" and other poems and usefully observes that the poem considers historical "ground" as "not only contested territories but also the identifying stamp that inhabitants place upon them" in following the "nature of colonial consumption" (pp. 54-55). 
ideal of progress and obscured the racial and ethnic conflict that marred the nation's past. (Shaffer 2001, pp. 194-95)

Not unlike a travel guide, "Virginia Britannia" selects and marks historic sites to present a "particular narrative" of America, opening the poem by stepping onto the grounds of Jamestown, the first permanent settlement by the English, founded in 1607. However, in both its form and content, Moore's tour challenges the idealization of an American tradition as inherently a movement toward progress enabled by the young nation's commitment to freedom. In part, this challenge takes place through the taxonomic gestures of the poem. In its densely close and precise attention to observing and recording natural detail, its persistent architecture of cataloguing and classification, this poem participates in methods of taxonomy that are associated with natural history since the seventeenth century, applying them to the experience of the historic tour.

Taxonomy is a branch of science that encompasses the description, identification, nomenclature, and classification of organisms. It privileges visual economies of empirical observation first brought into taxonomy in the late-seventeenth century by the botanist John Ray, who influentially asserted the notion of "species" as the ultimate unit of taxonomy (afterward debated by Linnaeus, Darwin, and others). Natural history, as based upon taxonomic observation and categorization of all manifestations of life, emerged coincidently with the transatlantic slave trade, and the exploration and colonization of the new world essential to establishing the American nation. European encounters with non-white populations found a logic in applying taxonomic systems to human groups, evolving an Enlightenment justification for racial hierarchy and oppression endemic to America's nation-building.

An intergenerational pondering of American taxonomies of race can be traced along lines that move from Moore back to Thomas Jefferson and forward to contemporary poet Natasha Trethewey. Collusions of racist thinking and racial mixing, of course, distinguished the colonizing of North, Central, and South America, and the eighteenth-century founding of the United States as a nation. Writing from his home in Charlottesville, and many years before his slave, Sally Hemings (born in 1773) most likely bore his children, Thomas Jefferson struggled with the undeniable presence of miscegenation in the new country. He turned to the logic of taxonomy then defining the field of natural history and embraced by Jefferson in organizing his extensive collections and classifications of American specimens of flora, fauna, and wildlife. His extensive field guide, Notes on the State of Virginia, written in 1781, is informed by the new scientific method of taxonomy that was introduced by Carl Linnaeus, a way of cataloguing, dividing, and subdividing all elements of the natural world. Jefferson's project responds, in part, to the French naturalist Goerge Louis Lecler, comte de Buffon, whose popular natural history volumes sought to move taxonomy from endless classifications and subclassifications to broader questions of "why" and "how" species developed and differed. Volume V of Buffon's monumental Histoire naturelle applied that question to the American colony's natural world, arguing, in his "Theory of American Degeneracy", that the animals and people of the New World were naturally weaker and smaller than those in the Old World, and that the migration from the Old to the New inevitably jumpstarted a process of degeneracy for any species. Notes on Virginia attempts to disprove Buffon through empirical taxonomies that illustrate the vigor of American flora, fauna, and people, linking the American natural world to its capacity and distinctions as a nation.

The diversity of the natural landscape extends into the diversity of its population, and Jefferson strives to provide an ordering vision, analogous to the natural world, of the varied races peopling the country. In pages that are famously painful for their appeal to scientific logic but rife with social prejudice, Jefferson argues that the "races of black and of red men ... have never yet been viewed by us as subjects of natural history", a step he then undertakes to correct. While praising the Indian as sublime evidence of American vitality, he advances his "suspicion ... that the blacks ... whether originally a distinct race, or made distinct by time and circumstances, are inferior to the whites in the endowments both of body and mind". Turning to principles of taxonomy, he argues, "different species of the same genus, or varieties of the same species, may possess different qualifications". Justifying his "suspicion" through classification systems shaping ideas of natural history, Jefferson argues race is 
a "difference fixed in nature", and infamously comments that the "improvement of blacks in body and mind, in the first instance of their mixture with whites, has been observed by everyone, and proves that their inferiority is not the effect merely of their condition of life" (Jefferson 1984, p. 264). The assumption that a mixture with whites improves blacks, but that such a mixture degenerates whites and makes them and their descendants forever non-white, forms the basis, of course, of both American custom and slave-holding law, in which the mother's status as a slave determined the status of her child, no matter the father. After slavery ended, the one-drop laws that were adopted throughout America continued this logic of racial distinction and ancestry. Such historical thinking about racial difference, Trethewey's poems insist, continues to persist in the public imagination.

Trethewey's Thrall (Trethewey 2012) tracks past and continuing traces of this taxonomic logic, particularly its privileging of visual "evidence" to determine racial identity. Addressing Jefferson's Virginia home Monticello, in "Enlightenment", and the Spanish colonization of the Americas, in a stunning poetic sequence aptly titled "Taxonomy", Trethewey excavates European and early American taxonomies of race to trace how this logic persists into the present day, especially in the intersections of private and public relations. "Taxonomy" dwells upon the casta system defining New Spain's colonizing hierarchies of race, while "Enlightenment" links Jefferson's theories and experiences of racial mixing to similar taxonomies continuing to shape current social discourse and her own mixed-race family history.

The poems that make up "Taxonomy" consider how the taxonomic methods of ordering the natural world are applied to social organization, as displayed by the genre of family portraiture known as casta paintings and the specific artwork in this genre by Juan Rogríguez Juárez. Casta paintings vividly visualize human taxonomies organizing race in the seventeenth- and eighteenth-century colony of "New Spain" (now Mexico). Acknowledging that at least five hundred casta paintings were produced in the eighteenth century, Diana DiPaolo Loren notes that these "idealized family portraits" were produced "primarily for elite audiences in Spain", and the "sets of consecutive images ... were meant to be prescriptive as they followed a specific pattern of illustrating social differences that resulted from the union of people of different races". The social differences followed the "race of offspring", which "defined the family's place in colonial culture" (Loren 2007, pp. 24-25).

Documenting the carefully calibrated systems of racial designation ordering the colony, the series of casta paintings done by Juan Rodríguez Juárez in 1715 stages the classifications of colonial racial mixing emerging from Spanish encounters with Africans and Indians. Insisting upon a visual economy that naturalized social hierarchies, the paintings portray what Trethewey's "Taxonomy" calls a "catalog/of mixed bloods" and a "Guidebook to the colony" that the official "Book of Castas" - government and parish books recording births, deaths, baptism, marriages, etc.-carefully adhered to in classifying racial identities based on lineage (Trethewey 2012, p. 24). Charting the process of miscegenation, casta paintings illuminate the ranking of individuals of mixed-blood ancestry, as "those with more Spanish blood were at the upper end of the scale, while those with more African or Native American blood tended towards the bottom of the scale" (Loren 2007, p. 23). This system of categorization, known as the "sistema de castas", emerged during the seventeenth century to provide a "hierarchical ordering of racial groups according to their proportion of Spanish blood"; while in "theory, one's place in the racial hierarchy was based on lineage", lack of knowledge regarding ancestral lines resulted in a greater stress on "skin color as a guide to racial status among commoners" (Cope 1994, p. 24). As with Jefferson in America, the sistema de castas argued that "moral and intellectual qualities were transmitted through heredity", and "those with less tainted, more Hispanic bloodlines should be superior to other castas" (Cope 1994, pp. 25-26). Although the sistema de castas included upward of forty categories of racial mixing, most typically five to seven rankings were generally pertinent: "de Espanol" (Spaniard white), "da negra" (African black), "de India" (Native Amerian), the mestizo (white and Indian), the mulatto (white and black), the morisco (mulatto and Spanish), and the castizo (the mestizo and white) (Cope 1994, p. 24). 
Anxiety regarding racial purity, linked to fears of rebellion and seeking to counter the earlier fluidity of racial mixing, especially among white Spaniards and Indian women, underlies the "catalog/of mixed bloods" and its definitions of progression or regression. Three of the four sections that make up "Taxonomy" employ the titles of casta paintings signifying different mixtures, while using language supplied by the "Book of Castas" that held official listings of the "various mixed unions of colonial Mexico and the children of those unions whose names and taxonomies were recorded", as Trethewey's end-notes describe the system (Trethewey 2012, p. 81). The sequence's final poem is named for this book, while the first three poems take their titles from paintings reiterating the official language used for racial designations in the official record: "De Español y de India Produce Mestiso"; "De Español y Negra Produce Mulato"; and, "De Español y Mestiza Produce Castiza". Ekphrastic responses to each of these paintings by Juan Rodríguez Juárez, the poems continually return to the language of racial taxonomy that fixes the individuals into categories, the words (also painted by the artist into the scene) that shape their social position and are taken to fix their essence as raced beings.

In the second poem, the mixture of the white Spaniard man and black woman is the "mulato", "fixed in his place" by a visually determined lexicon, by "word", "image", and "brush stroke" (21). Unlike the "mulato", fixed in place, the "castiza" of the third poem is more fluid in moving among racial categories, for the "castiza" is considered to be one-quarter "white" as the offspring of a Spaniard and a "mestizo", the term for a mixed Spaniard and Indian. The child depicted "turns toward the father/reaching to him/as if back to Spain", forecasting her own offspring's possible return to whiteness that the poem tracks:

to the promise of blood

alchemy—three easy steps

to purity:

from a Spaniard and an Indian, a mestizo;

from a mestizo and a Spaniard, a castizo;

from a castizo and a Spaniard, a Spaniard. (Trethewey 2012, p. 23)

Jefferson postulates that the black is improved by a first mixture with the white, but that pure whiteness cannot tolerate any mixture with the black. In making further distinctions, the sistemas de casta differentiated between the effects of mixing black or Indian "blood" with "white" blood. Most strikingly, the mixture of Indian and white blood allows for a future cleansing of the blood to regain white racial identity. In this taxonomic typology of miscegenation, the return to whiteness remains open for the "castiza" (the light-skinned Indian and white), whose union with de Espanol produces-de Espanol, a procreative blood mending, a progression back toward whiteness.

Trethewey's "Taxonomy" records this "alchemy" for the Indian/white mix, while the "mulato" carries a "typology of taint/of stain: blemish: sullying spot", never leading to "pure" whiteness, even through a continued chain of generational miscegenation, always existing in the not-quite-white state of the "mulatto-returning-backwards" in variations of mixtures of African, white, and/or Indian (Trethewey 2012, p. 24). This phrase from the Book of Castas appears as a title for one of the casta paintings by Juárez, "De Mulato y Mestisa, Produce Mulato es Torna Atrás": “In Juárez's painting, the phrase 'mulato es torna atrs' literally means 'mulatto, return backwards', indicating that such a union was actually seen as a step backwards towards a more African heritage" (Loren 2007, p. 23). Trethewey's notes on "Taxonomy" at the end of the volume stress the "return backwards": "the widespread belief in the 'taint' of black blood—that it was irreversible-resulted in taxonomies rooted 
in language that implied a 'return backwards'" (Trethewey 2012, p. 81). Her poem supplies an alternative phrase for the "mulatto-returning-backwards (or/hold-yourself-in midair)" (tente en el aire) (Trethewey 2012, p. 24). These phrases suggest the fear of blackness returning, of parents who look white having a dark child because of the "taint" of blood returning. This fear suggests the English equivalence of "torna altrás" as not only "return backwards", but as "throwback", as in a throwback or return to blackness.

"Taxonomy" records how official and colloquial language enforces racial taxonomies: the "morisca [light-skinned offspring of mulato and Spaniard], the lobo [African \& Indian mix], the chino [from "barcino", a zoological term for horses with dark spots]/sambo [from the Spanish "zambo", the mixture of African and Native American], albino [child morisca and Spaniard, 1/16th black], and//the no-te-entiendo-the/I don't understand you" (Trethewey 2012, p. 24). This last label speaks to the fear of disorder from white and black mixtures, the failure of visual means to determine race if black blood can lurk in the seemingly white-appearing body and subsequently "torna altrás", or return backwards. Progressions of mixtures involving black lineage end up in uncertainty and unrecognizability within these taxonomies of race.

These centuries-old taxonomies infuse a central moment of tourism in Thrall, recorded in "Enlightenment". The use of tourism to reinforce or alter historical narratives of American history, chiming with Marianne Moore's "Virginia Britannia", links a founding father's Enlightenment-era taxonomic theory of race to the present day through a focus on place as historical narrative. Trethewey, the daughter of a white father and a black mother, turns to Jefferson's presence and ideas in "Enlightenment", a poem near the end of Thrall that culminates reflections on taxonomy bookending the volume. This moment is staged as a tourist visit she and her father take to Jefferson's eighteenth-century home, Monticello, outside of Charlottesville, Virginia. This moment of tourism, the engagement with and consumption of a historical place, registers within the taxonomic structures linking natural history and social organization.

As though bringing us into Monticello's front door, the poem opens with a "portrait of Jefferson that hangs" in the entrance hall, "his forehead white with illumination-/ a lit bulb—the rest of his face in shadow", suggesting "his bright knowledge, its dark subtext". We are told, as though by a tour guide, that "By 1805, when Jefferson sat for the portrait/he was already linked to an affair/with his slave" (Trethewey 2012, p. 68). Trethewey's Monticello tour records a certain puncturing of an idealized mythos of Jefferson that underwent particular pressure with the revelations of DNA tests in 1998 showing shared heritage of his descendants and those of his slave Sally Hemings, although hypotheses and speculations of this relationship preceded the scientific experiments.

The visit that Trethewey and her father take to Monticello is their second one together, and it follows, chronologically, upon the genetically-enabled picture emerging of Jefferson's relation with his slave Sally Hemings—stories of a liason and offspring long "haunting" Jefferson's Charlottesville (and my home town), debated but just as often popularly debunked as incompatible with the Founding Father. In much the same way, during their previous visit to Monticello and prior to the DNA tests, Trethewey's white father refused to believe the rumors. He had "explained the contradictions", insisting "how Jefferson hated slavery, though—out/of necessity, my father said-had to own slaves; that his moral philosophy meant//he could not have fathered those children:/would have been impossible, my father said" (Trethewey 2012, p. 69). Such a sense of history reveals the tourist moment as one constructed to privilege "certain meanings and myths while ignoring others, deliberately arranging historical events and anecdotes, intentionally framing certain scenes and views into a coherent national whole" (Shaffer 2001, p. 4). The poem suggests the father's change in opinion is coincident with a change in the national narrative, from the time of their first visit to Monticello to this one, in his thinking about "this history/that links us-white father, black daughter" (Trethewey 2012, p. 71). Yet, despite the DNA tests and a softening of her father's convictions, Trethewey still understands that "the past holds us captive" in what she suspects is his lingering, unspoken belief in Jefferson's theory that the black's "mixture with whites" as a taxonomic improvement applies to her-like the taxonomies of 
the casta system and paintings-suspecting "my father could believe" that in his contribution of white "blood" to a child borne with a black woman, "he'd made me better" (Trethewey 2012, p. 70).

The poem's final stanzas suggest the persisting impact of old taxonomies of race, descending from the colonial Americas, which exhibit themselves not only in her father's unspoken thoughts, but deeply and extensively reside in assumptions of our national narrative. Even as the tourist site strives to change the narrative-as Monticello has committed itself to doing-and to make visible in its twenty-first century excavations, studies, and discussions of racial histories so long elided in narratives of Jefferson, the mechanisms of whiteness persist in this place in both proclaimed and unexamined assumptions of racial superiority. The poem lingers on how even the unveiled evidence of Jefferson's own complexities and contradictions regarding race get filtered through the taxonomies he clung to: even though so much "has changed" on the grounds of Monticello and in the presentation of the tour, "talk of Sally Hemings" inevitably leads to "someone asking" the tour guide: "How white was she?-parsing the fractions as if to name what made her worthy of Jefferson's attentions: a near-white//quadroon mistress, not a plain black slave" (Trethewey 2012, pp. 70-71). As in the casta system, whiteness remains the desired, but unattainable, standard, for if Hemings is almost white, the Founding Father's acts might be understood. This justification for Jefferson's attraction to Hemings, for Trethewey, bespeaks continuing and often unconscious assumptions of white superiority infusing American habits of racial distinction.

\section{Visiting the "Serpentine Shadows"}

Read in conjunction with Trethewey's poems and their direct engagement with taxonomies of race and American history, Moore's own formal reliance upon taxonomy in "Virginia Britannia", which manifests an obsessive cataloguing that gestures toward taxonomic classifications, raises questions about human classifications endemic to America's origins. Moreover, reading the two poets together, as each visits historical sites and especially as each invokes places related to Thomas Jefferson, reveals a concern with how taxonomic processes of classification imbricate tourism's engagement with historical place. How, for each poet, is the structure of the touristic encounter determined by taxonomies linking natural history and social organization?

In its touring observations, Moore's poem adopts a classificatory model of taxonomy to detail natural elements of plants, birds, trees, and wildlife, placing them alongside artificial structures of man-made gardens, cemeteries, and churches. In these juxtapositions, the poem sets up an American taxonomy of natural history that comments upon the construction of an imperial "landscape" to duplicate England's:

\section{... The Old Dominion has}

all-green grass-hoppers in all-green, box-sculptured grounds; an almost English green surrounds

them. Care has formed among unEnglish insect sounds,

the white wall-rose. (Moore 1936, p. 4)

The insistently hyphenated words, along with the syllabically broken words ("a-/mong") ending lines, suggest here and throughout the poem how the hybrid domestication of this landscape is also a kind of breaking and making strange, as in the importation of the English rose among "unEnglish" environs to create an "almost English green" among the lands that "Indians knew" differently. Nonetheless, the native environment persists, as in the "terse Virginian" mocking-bird who alights on garden furniture among the artifice of "Narrow herring-bonelaid brikes" and imported pansies (Moore 1936, p. 5). In such lines, Moore's taxonomic approach, like Jefferson's before her, rejects the notions of superior British/European flora, fauna, people, even parodying the attempts to create an English environment in this new world. However, unlike Jefferson, the poem attends to the types of 
tyranny imported, alongside the English garden designs, to suggest a "tyrant taste" that underscores European colonization and a national history that includes genocide and slavery. ${ }^{7}$

Identifying an American pattern of oppression in the histories that underpin the sites she tours, this tourist perspective captures distinctively visual enumerations of colonizing force-proceeding through place by citing visual evidence of what the poem calls "taking what they/pleased - colonizing as we say-" (Moore 1936, p. 8). Seeing boxed flower beds and sculpted gardens, for example, the speaker reads into the shaping of nature a colonizing ideology of tyranny that justifies itself as a "kindness". The poem's touristic cataloguing lays bare the oxymoron and contradiction of America's founding moment, its "inconsistent flowerbed" of protest against tyranny and simultaneous adoption of it, particularly pointing to the treatment of Native Americans and black slaves (Moore 1936, p. 6). Her natural history is carefully intertwined with a social history of colonial locations, primarily Jamestown and Williamsburg, and with a location that has taken on new meaning in relation to racial attitudes in twenty-first century America, the city of Charlottesville. ${ }^{8}$ The touristic encounter with Jefferson's home, in Trethewey, and the university, in Moore, offer complementary opportunities to consider American racial attitudes borne of applying natural history taxonomies to social organization. Jefferson's Notes on the State of Virginia haunts both poets, with Trethewey quoting directly from his text, while Moore's poem both echoes and questions the taxonomic approach that, accompanying the history of American colonization and nationhood, essentialized and hierarchized race.

Jefferson's appearance in "Virginia Britannia" is oblique in Moore's poetic text, but explicit in the notes. Moore cites Jefferson through referencing an architectural innovation, the curving serpentine wall, constituting an homage to good design common to Moore's poetics. ${ }^{9}$ The fleeting reference morphs in significance, however, from seeming praise to a more complex critique when one considers its placement and relation to the images that precede and follow it in the poem. In one quick moment, Jefferson-Enlightenment practitioner of "new" taxonomic methods-appears (unnamed in the poem) through the image of the serpentine walls distinguishing his architectural design of the University of Virginia, the "one-brick-thick-/wall serpentine shadows" dividing the campus gardens surrounding the main Lawn and the "Range", parallel rows of small student rooms conjoined down the length of the lawn, punctuated by large stately faculty homes, and descending from the classical-inspired dome of the Rotunda (Moore 1936, p. 7). Moore's choice to include Thomas Jefferson and his edifice to education as a part of this sequence is emphasized by her decision to provide the University a rare footnote, in a poem chock-full of perplexing and dense references and allusions but short on notes (unlike "An Octopus", with its pages of notes-although characteristically incomplete). Her note on Jefferson becomes one of a sparse few notes for this long poem, telling us that the "serpentine shadows" are "Of the University of Virginia's one-brick-thick wall designed by Thomas Jefferson", an engineering ingenuity that he adapted from England, but was popularly thought to have invented (Moore 1936, p. 23). Jefferson's own history of owning slaves, of involving them in the labor of building his home and University, and his uneasy rationale in Notes on Virginia, where cataloguing flora and fauna leads to justification for classifying humans, compromise the virtues of "intel-/lect and delicacy" advanced by selective and dominant depictions of the nation (Moore 1936, p. 8). These "shadows", like the broken word "intel-/lect", suggest the paradox Trethewey later terms, in speaking of Jefferson, "his bright knowledge, its dark subtext" (Trethewey 2012, p. 68).

7 See Tara Stubbs, discussing ideas of nationality in this "Virginia Britannia" and other poems, who usefully observes that the poem considers historical "ground" as "not only contested territories but also the identifying stamp that inhabitants place upon them" in following the "nature of colonial consumption" (Stubbs 2016, pp. 54, 55).

8 The white supremacist rally, Unite the Right, took place in Charlottesville on August 11 and 12, 2017 and brought far-right and white nationalist groups to the city, where they marched on the campus of the University of Virginia and gathered in a downtown park to protest plans to remove a statue of Confederate general Robert E. Lee. After the rally, a Unite the Right supporter drove a car into a crowd of counter-protesters, resulting in nineteen injuries and the death Heather D. Heyer. See: https://en.wikipedia.org/wiki/Unite_the_Right_rally.

9 See Kinnahan (2018) for a further reading focused on economics, labor, and race in Moore's work, including “Virginia Britannia" but also earlier poems. 
The image of the serpentine walls suggests the beauty, strength, and engineering ingenuity of the walls (which can "star-/tle strangers"), but also specifies their "shadows", a word that tellingly opens onto a series of references to natural and historical colonizers. This series culminates in a consideration of race:

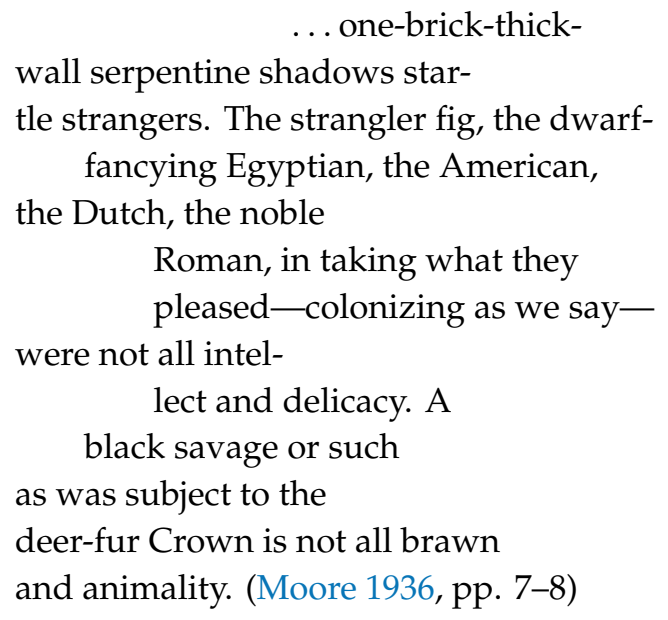

This imperial "taking what they/pleased" includes those that are deemed as the "black savage" and the "subject to the/deer-fur Crown", characterizations of Africans and Native Americans importantly relying upon the classification of human types, placing whites at the top of a racial hierarchy, which Jefferson (and others) deploys and that the mythos of Manifest Destiny promoted (Moore 1936, p. 8). The poem emphatically challenges this taxonomic justification for enslavement and/or genocide, insisting that the African and the Native American are "not all brawn/and animality", speaking as much to her own moment of racial strife and political xenophobia in America as to the past (Moore 1936, p. 8).

Moore's tour deviates, in such moments, from the popular approaches to tourism that she herself consulted. The tourist industry at this time directed its selling pitches to white Americans. Travel guides, like the See American First series, recounted "a history of American progress that glorified white, Anglo-Saxon America, thus allowing for tourists to retreat into this idealized America, escaping the realities of racial and ethnic conflict and other growing tensions in American society" (Shaffer 2001, p. 199). Moore, whose tourism experiences became-like everything-gist for her poems, conveys an uncanny sense of the early twentieth-century tourist industry as a vehicle for presenting a history of America that suits the racial priorities of the post-war decades of the twenties and thirties. In a nation experiencing intensified race conflict, non-white population migrations, and terroristic violence against blacks, the tourist industry in the teens, twenties, and thirties actively discouraged blacks from visiting historical sites, while tour guides presented a history in which they disappear. ${ }^{10}$ Thus, Clifton Johnson's 1922 tour book What to See in America, quoted by Moore in the earlier "An Octopus", clearly assumes the (unmarked) whiteness of the American tourist. The chapter on Virginia, for example, which is heavy in describing sites of Civil War history, only indirectly mentions slavery through a lens of natural harmony: in the one sentence noting the "one third of the population" of the state who are "negroes", Johnson assures his tourist that such numbers present no threat, and the "negroes" "are mostly employed in the tobacco factories, where they amuse themselves as they work in singing the quaint old plantation melodies" (Johnson 1922, p. 150). The "old plantations"

10 As Shaffer relates, "the Park Service consciously discouraged African Americans from visiting the parks. As stated at the 1922 parks conference, 'One of the objections to colored people is that if they come in large groups they will be conspicuous, and will not only be objected to by other visitors, but will cause trouble among the hotel and camp help, and it will be impossible to serve them ... While we cannot openly discriminate against them, they should be told that the parks have not facilities for taking care of them'” (Shaffer 2001, pp. 124-25). Conditions of segregation throughout the country, but especially in the South, motivated the publication of the annual Negro Motorist Green-Book from 1936 until 1964 to provide black travelers with information about businesses and services friendly to African Americans. 
pictured in photographs accompanying the chapter are those of American "heroes"-Washington, Lee, and Thomas Jefferson-although the picture captions do not call them "plantations", nor is there any mention of slaves who built and maintained them.

In the midst of her taxonomic and precisely structured syllabic lines, Moore unsettles tourism's white-washed histories, whether they be Johnson's touristic assurance to whites that the "negroes" only raised their voices harmlessly in song, or Jefferson's earlier denial of speech to the "black". Jefferson's human classifications explicitly denied that blacks had a capacity for coherent speech, for he writes, "never yet could I find that a black had uttered a thought above the level of plain narration" (Jefferson 1984, p. 267). Conversely, the poem specifies a more complex understanding of voice, evoking a "Black/idiom" to which Moore attributes the phrase that she uses in describing an alternative perspective on the nation's history, one gained through "advancing back-/ward in a circle" (Moore 1936, p. 6). Fiona Green locates this phrase in Moore's travel notebooks from her Virginia visits, in which she "began recording black speech" (Green 2017, p. 439). In August, 1935, gathering material for the poem that she will soon begin drafting, Moore writes of a witness in court who reports about a "colored man in court" that she "saw him advancing backward in a circle, a piece of scantlin' in his hand" (Moore 1935-55, 4v, quoted in Green 2017, p. 440). Green reads this reference and its incorporation into the poem as suggesting "shady business" or even "making light of the crime at the heart of Virginia history", conveying Moore's "genuinely ambivalent" attitude toward southern economies rather than critiquing them (Green 2017, p. 440). ${ }^{11}$ However, the backward circling that Moore records suggests a defensive motion; indeed, the man holding a "scantlin"' or scantling (a piece of lumber) seems to be more protective than "shady", his circling backwards comprising an alternative stepping to outsmart an opponent more so than an aggression.

The movement suggests a different kind of knowledge bridging "black idiom" as coded speech with Tretheway's retrieval of racial labels, chiming with the "mulatto-turning-backwards". This turn backwards signifies the body's language and its disruption of racial categories (the revelation of "blackness" in the seeming white body, or the whiteness turning "backwards" to African origins) as well the racist ideology determining illusory classifications of purity. The mulatto-turning-backwards threatens a throwback to blackness and a refusal of purity mythologized in the Americas' earliest racial categories - the mulatto is both a threat to visual certainty of race and she/he holds the potential to visually disrupt an illusion of whiteness, even while the categorizing rationale of whiteness insists that blackness never retreats and that the descendant of an African can never become "white". The notion of "advancing backward in a circle" similarly registers a movement through concealed knowledge, covered-over and retreating from view but threatening to return and thwart history's racialized categories. Such thwarting challenges the concept of nation idealized as free of "tyranny".

This is the "scantlin"" held in hand, brought to bear in the poem's repeated references to imperialism, colonization, and racial ordering, and activated with particular force in the serial images following the introduction of the "Black/idiom". Moore is "advancing backward" through America's originary claims, bringing a poetic stick to bear. The logic of the lines moves swiftly in the space of nine lines from the "Black/idiom" through a quick reference to colonizing Europeans ("taking the Potomac/cowbirdlike", for the cowbird lays eggs in another bird's nest, colonizing it), to the "Negro, opportunely brought", as the "backward" movement of bringing slaves to the new world translates into the "idiom" (Moore 1936, p. 6). As a trade that strengthens the colonies' financial might and capacity for successful revolt, but betrays the principles asserted for doing so, "the Negro" who is "opportunely brought, to strength-/en protest against/tyranny" speaks to the "inconsistent flowerbed" of the Old Dominion and is, indeed, a "backward" movement justified as forward progress in the colonies and among imperial powers (Moore 1936, p. 6). The breaking of "strength-en" across two

11 Green reads Moore's ideas about economy, nation-building, and history in relation to the poet's correspondence with and readings of Ezra Pound. Green attributes the idea that the image of "advancing backward in a circle" might reference a cake walk, or a black performance parodying white power, to Stacy Hubbard (Green 2017, p. 447). 
lines suggests the inherent flaw or weakness in this revolt against a tyranny that, in dropping that word onto a new line, remains a characteristic that is attributed as much to the new nation as to the old. The "kind tyranny" referenced repeatedly in the poem reads, in this context and others in which it appears, as a sly critique of the oxymoronic justifications offered for any number of oppressions suiting "tyrant taste" in America's history of race, colonization, and capitalistic progress-indeed, the poem seems to ask, how can tyranny ever be "kind" (Moore 1936, p. 8)?

Rather than following the ideology or mythology of American progress as a constant forward motion, this "idiom" adopts alternative strategies and directions, suggesting an idiom of the indirect, the outside, and the marginal that motivates a retelling of colonial might. Rather than exemplifying the forward progress of history, the building of the American nation that is celebrated by these tourist sites suggests instead a series of displacements undertaken in the name of power and re-narrativized in the poem through botanical, biological examples of parasites and colonizers: displacing others "cowbirdlike" or, like the "fig strangler", which establishes itself upon a host tree it destroys, gaining a foothold through conquering others. These "colonizers" in nature are joined by other natural species that are specified in the poem, such as the crape myrtle or the pansy, all imported from Europe and, while dominating Virginia gardens, unable to subdue native flora and fauna, such as the buckeye tree or the Virginia mockingbird or the rattlesnake. Catharine Paul notes that "Moore's choice of species" in this poem is "linked to a larger commentary on how the native and the coloniser might collide" (Paul 2002, p. 190). Such a poetic presentation of history, which Westover usefully terms a "cartography of colonization", also maps the forced import of African people to build the "garden" and the economy of a new land, the use of slavery to create a nation (Westover 2004, p. 40). The oxymoronic tyranny of "establishing the Negro, opportunely brought, to strength-/en protest against/tyranny" joins the taxomomies of Moore's touristic moment.

Moore's double reference to the mule in lines that precede reference to a "black idiom" reinforce a reading of race as a site interrupting a white-washed mythology of American freedom. The mule, a "cross between a horse and a donkey", serves as "a perfect image for the miscegenation that troubled nativists" in Moore's time and vexed Jefferson. ${ }^{12}$

quick calvacade

... The slowmoving glossy, tall

of buckeye-brown surprising

jumpers, the contrasting work-mule and

show-mule \& witch-cross door \& 'strong sweet prison' (Moore 1936, p. 8)

All items in this sequence exemplify or have "come about" from "advancing back-/ward in a circle", including the first prison in the British colonies, established at Jamestown to discourage disorder in the new land but, the poem suggests, importing a "tyranny" (Moore 1936, p. 6). "Advancing back-/ward", one discovers traces of other histories disrupting the touristic, patriotic, and historic claims that idealize the country's revolutionary past and ideals of equality. The "Indian-/named Virginian/streams" run through "counties named for English lords" as native lands are overtaken and overwritten by European conquest (Moore 1936, p. 7); the "tobacco-crop/gains have church tablets", as commerce and piety intertwine (Moore 1936, p. 7); the "Devil's woodyard swamps", signaling histories of runaway slaves, conjoin in a parallel syntax with the "one-brick-thick" serpentine walls of Jefferson's university, its "shadows" part of the history of the powerful "taking what they please" (Moore 1936, pp. 7-8).

12 Westover (2004, p. 22). See also Kadlec (1994) and Phillips (1982) for discussions of Moore's work in light of contemporaneous discourses on eugenics and racial mixing. The figure of the mule appears also in Moore's earlier "The Labors of Hercules" (written in 1921 and included in Observations, 1924) and has been critically discussed as a criticism of notions of white superiority, especially in light of immigration debates and restrictions following the war. 
Throwing light on the "shadows" or "dark subtext" of a celebrated version of American history, both Moore and Trethewey inspect the racial dimensions of nation building. Doing so, they consider inherited Jeffersonian taxonomies of race alongside the mechanisms of taxonomic logic itself. Both of the poets question how taxonomies of race imprinted upon and furthered by the founding contradictions of this country continue in everyday ways that seem common-sense in their familiarity (i.e., she is "near-white"), but are made strange in the step away from taxonomic thinking that each poet encourages. Given the rise of white supremacist activity in America over the past few years, evidencing energy and ideological organization that has remained for a long time submerged and out of sight for the majority public, a renewed urgency compels us to rethink and "make strange" longstanding racial and racist taxonomies and resist the false ideologies of whiteness attending the past and present imagination of "nation".

Funding: This research received no external funding.

Conflicts of Interest: The author declares no conflict of interest.

\section{References}

Cope, R. Douglas. 1994. The Limits of Racial Domination: Plebeian Society in Colonial Mexico City, 1660-1720. Madison: University of Wisconsin Press.

Jefferson, Thomas. 1984. Jefferson: Writings: Autobiography, Notes on Virginia, Public and Private Papers, Addresses. Edited by Merrill D. Peterson. New York: Library of America.

Johnson, Clifton. 1922. What to See in America. New York: The Macmillan Company.

Green, Fiona. 2017. Moore, Pound, Syllabics, and History. Twentieth-Century Literature 63: 427-50. [CrossRef]

Kadlec, David. 1994. Marianne Moore, Immigration, and Eugenics. Modernisms/Modernity 1: 21-49. [CrossRef]

Kinnahan, Linda. 2018. Marianne Moore and Modern Labor. In Twenty-First Century Marianne Moore: Essays from a Critical Renaissance. Edited by Elizabeth Gregory and Stacy Carson Hubbard. New York: Palgrave Macmillan, pp. 149-66.

Leavell, Linda. 2016. Holding on Upside Down: The Life and Work of Marianne Moore. New York: Farrar, Straus and Giroux.

Loren, Diane DiPaulo. 2007. Corporeal Concerns: Eighteenth-Century Casta Paintings and Colonial Bodies in Spanish Texas. Historical Archaeology 41: 23-36. [CrossRef]

Miller, Cristanne. 1995. Marianne Moore: Questions of Authority. Cambridge: Harvard UP.

Moore, Marianne. 1967. The Complete Poems of Marianne Moore. New York: Viking.

Moore, Marianne. 2016. Observations. Edited by Linda Leavell. New York: Farrar, Straus and Giroux.

Moore, Marianne. 1936. The Pangolin and Other Verse. England: The Brendin Publishing Company.

Moore, Marianne. 1997. The Selected Letters of Marianne Moore. Edited by Bonnie Costello, Celeste Goodridge and Cristanne Miller. Now York: Alfred A. Knopf.

Paul, Catherine. 2002. Poetry in the Museums of Modernism: Yeats, Pound, Moore, Stein. Ann Arbor: University of Michigan Press.

Phillips, Elizabeth. 1982. Marianne Moore. New York: Ungar.

Pound, Ezra. 1912a. Middle-Aged, A Study in an Emotion. Poetry, October 1, p. 8.

Pound, Ezra. 1912b. To Whistler, American. Poetry, October 1, p. 7.

Pound, Ezra. 1914. Wyndham Lewis. The Egoist, June 15, pp. 233-34.

Shaffer, Marguerite S. 2001. See America First: Tourism and National Identity, 1880-1940. Washington, DC: Smithsonian Institution.

Stubbs, Tara. 2016. 'Its Native Surroundings': Marianne Moore, England, and the Idea of the 'characteristic American'. Modernist Cultures 11: 48-64. [CrossRef]

Trethewey, Natasha. 2012. Thrall: Poems. New York: Houghton Mifflin Harcourt. 
Westover, Jeffrey W. 2004. The Colonial Moment: Discoveries and Settlements in Modern American Poetry. Dekalb: Northern Illinois University Press.

White, Heather Cass, ed. 2008. A-Quiver with Significance: Marianne Moore 1932-1936. Victoria: ELS Editions.

(C) 2019 by the author. Licensee MDPI, Basel, Switzerland. This article is an open access article distributed under the terms and conditions of the Creative Commons Attribution (CC BY) license (http://creativecommons.org/licenses/by/4.0/). 